\title{
DEVELOPMENT OF APPROPRIATE MECHANIZATION FOR THE 'W'-FORM SOIL MANAGEMENT SYSTEM
}

\author{
HARBANS LAL* \\ Department of Agricultural Engineering, University of Florida, Gainesville, FL 32611 \\ (U.S.A.)
}

(Accepted for publication 17 June 1986)

\begin{abstract}
Lal, H., 1986. Development of appropriate mechanization for the 'W'-form soil management system. Soil Tillage Res., 8: 145-159.

The 'W'-form soil management system consists of shaping the soil surface in the form of a ' $W$ ' with alternate wide and narrow ridges following the contour. The triangular section wide ridges serve as a rainwater harvesting zone, the trapezoidal section narrow ridges as the planting zone and the furrows as water-storage zones and pathways for animals and wheels. The system, which was designed to improve 'in-situ' rainwater harvesting and control of run-off and erosion, has also shown promising results in: (1) facilitating separate and selective tillage operations for different zones, (2) decreasing the animal and tractor hours requirement, (3) reducing compaction in the planting zone and (4) permitting localized application of soil conditioners, thus resulting in higher yield and ensured crop production. The operational requirements for implementing and reshaping the system are described in detail for two types of mechanization, one for animal traction and another for tractor traction. Implementation of the system requires $6-8 \mathrm{~h} \mathrm{ha}^{-1}$ with animal traction and $2-3 \mathrm{~h} \mathrm{ha}^{-1}$ with tractor traction as compared to $20-22 \mathrm{~h} \mathrm{ha}^{-1}$ and $6-8 \mathrm{~h} \mathrm{ha}^{-1}$ required in the traditional system of flat cultivation with animal and tractor traction, respectively.
\end{abstract}

\section{INTRODUCTION}

In the dry regions of northeast Brazil, the soil management and tillage systems traditionally used are not efficient enough to guarantee a satisfactory yield for common crops, even at subsistence level. The common practice used by the farmers in these regions is cultivation on the flat using one of the following options: (1) planting without any soil preparation after the soil has become sufficiently moist from initial rains, (2) planting after shallow plowing with animal-drawn reversible or simple moldboard plows, or (3) planting after moderate plowing with tractorized implements.

In all three cases, the first showers of the cropping season are not fully utilized. In the first case, the compact and dry soil has a low infiltration rate, which extends the time period required to moisten the soil to a sufficient

*Formerly Mechanization Specialist at IICA/EMBRAPA-CPATSA, Petrolina (PE), Brazil. 
Precipitation received at the Dry-land Experiment Station of CPATSA/EMBRAPA during $1981-1984^{\mathrm{a}, \mathrm{b}}$

\begin{tabular}{|c|c|c|c|c|c|c|c|c|c|c|c|c|}
\hline \multirow{2}{*}{ Year } & \multicolumn{12}{|c|}{ Month } \\
\hline & Jan. & Feb. & Mar. & Apr. & May & Jun. & Jul. & Aug. & Sep. & Oct. & Nov. & Dec \\
\hline 1981 & $\begin{array}{r}30.8 \\
(5 / 1)\end{array}$ & $\begin{array}{r}4.3 \\
(3 / 0)\end{array}$ & $\begin{array}{c}45.3 \\
(15 / 0)\end{array}$ & $\begin{array}{r}41.6 \\
(6 / 2)\end{array}$ & $\begin{array}{l}- \\
-\end{array}$ & $\begin{array}{l}- \\
-\end{array}$ & $\begin{array}{l}- \\
-\end{array}$ & $\begin{array}{r}1.7 \\
(1 / 0)\end{array}$ & - & - & $\begin{array}{l}15.0 \\
(2 / 1)\end{array}$ & $\begin{array}{r}11.4 \\
(5 / 1)\end{array}$ \\
\hline 1982 & $\begin{array}{r}73.5 \\
(5 / 2)\end{array}$ & $\begin{array}{r}26.4 \\
(3 / 1)\end{array}$ & $\begin{array}{r}51.5 \\
(7 / 1)\end{array}$ & $\begin{array}{r}44.0 \\
(6 / 1)\end{array}$ & $\begin{array}{r}1.4 \\
(1 / 0)\end{array}$ & $\begin{array}{r}8.3 \\
(6 / 0)\end{array}$ & $\begin{array}{r}4.1 \\
(3 / 0)\end{array}$ & $\begin{array}{r}10.2 \\
(2 / 0)\end{array}$ & $\begin{array}{r}7.4 \\
(3 / 0)\end{array}$ & - & - & $\begin{array}{r}42.3 \\
(4 / 1)\end{array}$ \\
\hline 1983 & $\begin{array}{r}77.7 \\
(9 / 2)\end{array}$ & $\begin{array}{l}116.1 \\
(7 / 4)\end{array}$ & $\begin{array}{l}115.1 \\
(12 / 3)\end{array}$ & $\begin{array}{l}- \\
-\end{array}$ & $\begin{array}{r}4.1 \\
(1 / 0)\end{array}$ & - & $\begin{array}{r}17.5 \\
(2 / 1)\end{array}$ & $\begin{array}{r}0.9 \\
(1 / 0)\end{array}$ & $\frac{-}{-}$ & $\begin{array}{r}1.8 \\
(1 / 0)\end{array}$ & $\begin{array}{r}89.5 \\
(5 / 3)\end{array}$ & $\begin{array}{r}13.7 \\
(2 / 1)\end{array}$ \\
\hline 1984 & $\begin{array}{r}9.6 \\
(2 / 0)\end{array}$ & $\begin{array}{r}3.1 \\
(4 / 0)\end{array}$ & $\begin{array}{l}317.2 \\
(15 / 8)\end{array}$ & $\begin{array}{l}146.2 \\
(15 / 3)\end{array}$ & $\begin{array}{r}30.7 \\
(9 / 0)\end{array}$ & $\begin{array}{l}- \\
-\end{array}$ & $\begin{array}{l}- \\
-\end{array}$ & - & - & - & - & - \\
\hline
\end{tabular}

a Supplied by Mr. Malaquias da S. Amorin Neto, Agroclimatologist of CPATSA/EMBRAPA, Petrolina (PE).

b Figures in parentheses represent the ratio of total number of rainy days to the number of rainy days with $>10 \mathrm{~mm}$ of precipitation. 
depth for successful planting. In the second case, plowing with animal-drawn implements is generally accomplished after the first rain, thus losing a good part of the total seasonal rainfall. In the third case, although plowing with tractor implements can be done during the dry season, farmers in general delay it until the start of the rainy season. This is due to uncertainty about the start of the rainy season, and the possibility of a long dry spell after the first showers (Table I). In most cases, the farmers use hired tractors and they are hesitant to spend money until they are confident about the possibility of harvesting the crop to be planted. In these regions there is frequently no yield at all. Even a low plant population (10 000 hills $^{h^{-1}}$ as compared to 20000 hills $\mathrm{ha}^{-1}$ recommended by local research and extension agencies in northeast Brazil) does not help to achieve a reasonable crop yield. Under these conditions of uncertainty, the common farming system with minimum input: no fertilizer, no plant protection and a minimum of weeding, which is followed by the majority of the farmers, is understandable.

Under such circumstances, an integrated effort to develop alternative soil management and tillage techniques along with appropriate machinery systems which could improve the possibility of successful cropping in such regions, is well justified. The author, along with local researchers of the Agricultural Research Center for the Semi-Arid Tropics (CPATSA) of the Brazilian Enterprise for Agricultural Research (EMBRAPA), has been successful in developing a soil management and tillage technique which not only improves the soil physical properties to enhance water infiltration, but also redistributes precipitation to a small cropping zone resulting in higher available moisture for the planted crop.

Work with this orientation at the CPATSA started in 1977, with the testing of a broadbed-and-furrow system initially adopted by ICRISAT, India (ICRISAT, 1980). This system consists of broadbeds separated by furrows at regular intervals of $150 \mathrm{~cm}$. The furrows serve as pathways for animals and tool carrier wheels and for supplemental irrigation and drainage of excess water when the system is laid out on the slope. At CPATSA, experience with this system for application of supplemental irrigation has been very encouraging. However, for totally rainfed agriculture, its performance in the region for increasing and stabilizing crop production has not been very encouraging. In the 1980 rainy season, research on alternative soil management and tillage systems was started at CPATSA to compare two new types of soil configuration systems along with traditional flat and broadbed-and-furrow systems of cultivation. The new techniques, known as 'Metodo Guimaraes Duque' and 'Metodo CP-Mexico', were basically inclined bed systems and needed tractorized implements for their implementation and management (Silva and Porto, 1982). Yield levels obtained during the first year of experimentation (Table II) raised great hopes for increasing and stabilizing crop production using one of the new soil management and tillage techniques.

The performance of 'Metodo CP-Mexico' was excellent and this led to the search for appropriate animal-drawn machinery packages for its implementa- 
TABLE II

Yield level $\left(\mathrm{kg} \mathrm{ha}^{-1}\right)$ of cowpea under different soil management techniques, $1981^{\mathrm{a}}$

\begin{tabular}{|c|c|c|c|c|c|}
\hline \multirow{3}{*}{$\begin{array}{l}\text { Soil } \\
\text { conditioners }\end{array}$} & \multicolumn{5}{|c|}{ Soil management technique } \\
\hline & \multirow[t]{2}{*}{ Flat } & \multirow{2}{*}{$\begin{array}{l}\text { Broadbed } \\
\text { and furrow }\end{array}$} & \multicolumn{2}{|l|}{ New systems } & \multirow[t]{2}{*}{ Mean } \\
\hline & & & Method GD & $\begin{array}{l}\text { Method CP- } \\
\text { Mexico }\end{array}$ & \\
\hline Chemical fertilizer & 289 & 303 & 366 & 418 & 344 \\
\hline $\begin{array}{l}\text { Chemical + organic } \\
\text { fertilizer }\end{array}$ & 229 & 294 & 419 & 441 & 346 \\
\hline $\begin{array}{c}\text { Chemical fertilizer } \\
\text { + vermiculite }\end{array}$ & 319 & 402 & 383 & 361 & 368 \\
\hline Mean & 279 & 333 & 389 & 409 & 353 \\
\hline Relative (\%) & 100 & 119 & 139 & 147 & - \\
\hline
\end{tabular}

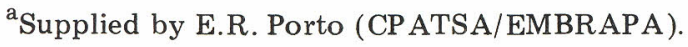

tion and management. Unfortunately, the available animal-drawn machinery did not suit the system. The Post Graduate College of Chapingo, Mexico, where the system was originally adopted, also encountered the same problem.

With these points in mind, efforts were continued to develop alternative soil management and tillage techniques which could be implemented and managed by available animal-drawn implements. The ' $W$ '-form soil management and tillage system is the fruit of these efforts. This paper describes the system's characteristics and operational requirements and the equipment set developed or adapted for its implementation and management.

The performance of the system in terms of crop yield, moisture variation and soil resistance to penetration, etc., has been described elsewhere (Lal, 1985).

\section{DESCRIPTION OF THE SYSTEM AND ITS ADVANTAGES}

The system consists of broad and narrow ridges alternately spaced on the contour. The broad ridges of the triangular section serve as a rainwater harvesting zone, the narrow ridges of the trapezoidal section serve as a planting zone and the furrows between the two as a water-storage zone and pathway for animals and machinery wheels. The furrows can also serve as drainage channels when the system is laid out on a slope. Figure 1 shows the schematic diagram of the system with possible crop configurations. For easy implementation and management of the system it is recommended that the areas of 
the planting zone and the water harvesting zone be maintained in the ratio of $1: 2$. This means that each unit of planted area receives extra runoff from two units of non-planted area. Gardner (1976), describing a similar system, designated the water harvesting zone as 'run-off area' and the planting zone as run-on area'. He also stated that run-off and run-on areas can be varied in width to alter the water collection characteristics. However, the maximum width of each area must be consistent with the water storage characteristics of the region and with the farm equipment that would be used. In view of the limitations of the animal-drawn wheeled tool carrier (the machine used for
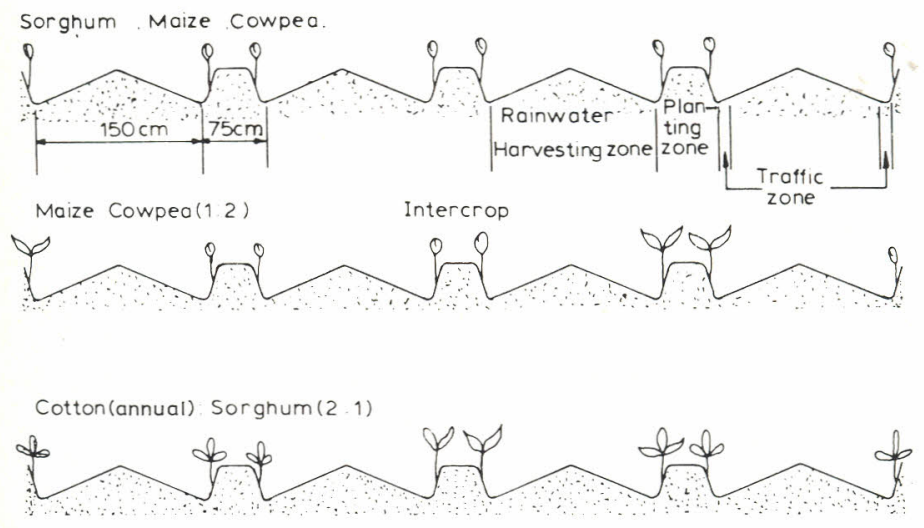

Cotton (perennial): Cowpea. Sorghum $(1: 1: 1$ )

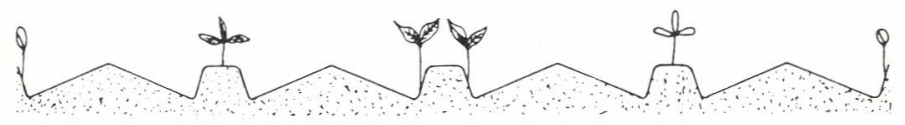

Cossava Cowpea $(1 ; 1)$

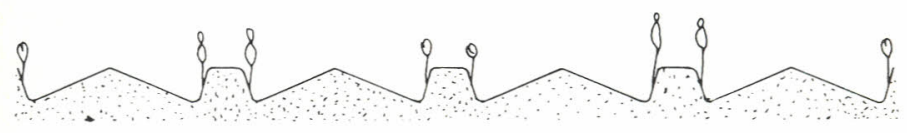

Palm Sorghum $(1: 2)$

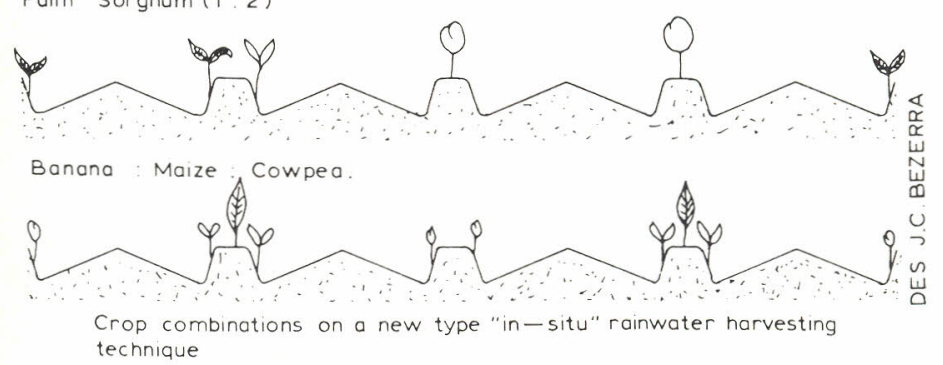

Fig. 1. Schematic diagram of the 'W'-form soil management system. 
the majority of the operations), the ' $\mathrm{W}$ '-system has been standardized with a $75-\mathrm{cm}$ wide planting zone and a $150-\mathrm{cm}$ wide water harvesting zone.

The system is basically designed to increase the availability of rainwater in the planting zone. Additionally, the system presents the following advantages: (1) it facilitates mechanization due to its symmetrical configuration; (2) it facilitates separate and selective tillage operations for the water harvesting and planting zone; (3) it is adaptable to supplemental irrigation; (4) it reduces soil compaction in the planting zone; (5) it concentrates organic matter and fertilizer in the planting zone; (6) it is easily maintained with minimum tillage; (7) it facilitates preparation during the dry season; and (8) it provides furrows for animals and machinery wheels.

\section{OPERATIONAL REQUIREMENTS OF THE SYSTEM}

The system can be implanted and re-formed by tractorized or animal-drawn implements especially developed for the purpose. However, other cultural operations, such as application of soil conditioners, planting and weeding are accomplished using an animal-drawn wheeled tool carrier or manual implements. So far, no serious efforts have been made to identify or develop appropriate implements for these operations. The traditional animal-drawn, single-purpose implements have been found to be unfit for the system because of their limited stability on the curvilinear path which the implement has to follow when the system is laid out on a uniform slope or on the contour.

The operational requirements for implementation and management of the system are described hereafter individually for different operations.

\section{Implementation}

The implementation of the system during the first year can be accomplished following normal land preparation or without any land preparation, depending upon the soil type and its condition. The sequence of operations consists of ridging the field along and parallel to the base-line ${ }^{\mathrm{a}}$ with three ridgers spaced at $75 \mathrm{~cm}$, followed by another operation with the ridger-blade (especially developed) to achieve the required shape of the water harvesting zone. For animal-drawn implements, if the system is laid out without land preparation, the number of passes required to achieve a satisfactory ' $\mathrm{W}$ '-shape depends upon the soil condition and the strength of the bullocks.

\section{Reformation}

The system can be maintained on a semi-permanent basis, thus needing only to be re-formed in consecutive years. The re-formation of the system

\footnotetext{
aThe base-line is the contour line or a line on the pre-defined slope marked out using common surveying instruments. The number of base-lines required depends upon the size and topographical variation of the area.
} 
using animal-drawn machinery, consists of plowing (if required) and/or ridging the planting zone and re-forming the water harvesting zone using the ridger-blade. On the other hand, the system can be re-formed by one single operation using a tractor ridger-blade.

\section{Application of soil conditioners}

The experience with the application of chemical and organic fertilizers, vermiculite and straw mulch in the ' $\mathrm{W}$ '-form system has been very encouraging. Farmyard manure (FYM) and vermiculite can be applied by opening a furrow in the centre of the planting zone. After manual or mechanical application, these materials are covered with a set of ridger bodies and a small metallic chain trailing behind the ridgers. For manual application of chemical fertilizers, small furrows are opened using cultivator tines attached to the toolbar of the tool carrier (Fig. 2), which are later covered by means of a set of ridger bodies as in the previous case. This procedure was used and is recommended when a suitable mechanical fertilizer applicator is not available. If required, the application of mulch can be carried out by spreading the material manually over the planting zone of the ' $\mathrm{W}$ '-form system.

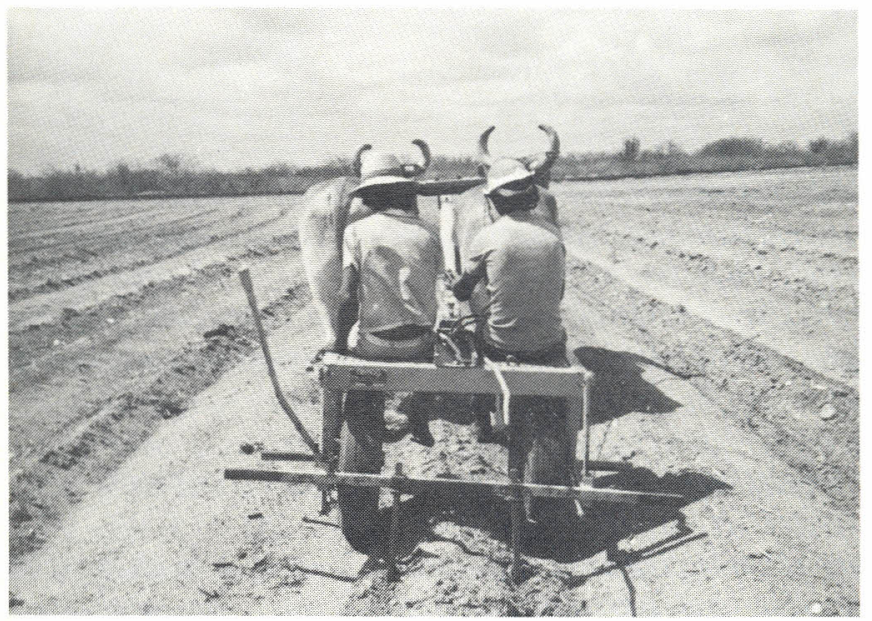

Fig. 2. Opening furrows for fertilizer application or manual seeding.

\section{Planting}

Planting on the ' $W$ '-form system is accomplished using one of the following procedures:

(1) For manual planting a technique similar to chemical fertilizer application is used. Small furrows are opened with cultivator tines and seeds are placed manually or using a dibbler know locally as 'Matraka' or 'Tico-Tico'. 
The dibbler can be used directly if the operation is carried out by an experienced operator.

(2) For mechanical planting, the planter must be of appropriate dimensions to accommodate two units within the space available in the planting zone, either as an independent unit or when mounted on the tool carrier.

Planting experience on the ' $W$ '-form system has been quite encouraging both with a manually operated dibbler and the unit planters of the wheeled tool carrier.

\section{Weeding and inter-row cultivation}

Weeding and inter-row cultivation for the ' $W$ '-form system are different from those of the conventional flat system of cultivation. The requirements of these operations for the water harvesting zone and planting zone need to be defined separately. In the system, $2 / 3$ of the area comprises the water harvesting zone and, therefore, the major concern has been to develop satisfactory equipment for this zone. Due to the sloping surface of this zone, a special implement is required. Initially, the ridger-blade itself was used for weeding the water harvesting zone, but while the ridger-blade worked satisfactory for uprooting or covering small weeds, it proved ineffective if the weeding operation was delayed. To improve delayed weeding operations, a special weeding-blade based upon the traditional Indian blade harrow (Lal and Nunes, 1980) has been developed which performed satisfactorily at different stages of weed growth.

For mechanical weeding and inter-row cultivation on the planting zone, a small-duck-foot attachment to the tool carriercan be used and complemented by hand weeding. However, because of the small width $(\sim 75 \mathrm{~cm})$ of the planting zone, it is expected that manual weeding of the complete planting zone will prove to be more economical than the combination of mechanical and manual weeding.

\section{EQUIPMENT PACKAGE FOR THE 'W'-FORM SOIL MANAGEMENT SYSTEM}

The equipment package developed for implementation and management of the 'W'-form soil management system can be divided into two categories: (1) equipment expecially developed for the system, i.e., the tractorized and animal-drawn ridger-blades and the animal-drawn weeding blade and (2) selected commercially available equipment for specific operations, i.e., sugarcane ridger, cultivator shovels and animal-drawn and manual planters (EMBRATER, 1982). The equipment and their operational characteristics are described below.

\section{Specially developed equipment}

\section{Tractorized ridger-blade}

Two commercially available tractorized ridgers have been modified to develop two models of ridger-blades. The first model has a $2-\mathrm{m}$ wide bar with 
three ridger bodies spaced at $75 \mathrm{~cm}$. Two metallic blades were bolted to the inner wings of the left and right side ridgers. To the end of the metallic blades chains are welded whose free ends are hooked to the tool bar to secure the metallic blades during field operation.

The second model of ridger has a $3.5-\mathrm{m}$ wide toolbar with two ridger bodies at distances of 75 and $150 \mathrm{~cm}$ from the centre of the toolbar on each side. To adapt this ridger to a ridger-blade, modifications similar to the first model were made on the two central ridger bodies. Figure 3 shows the second ridger-blade model in operation.

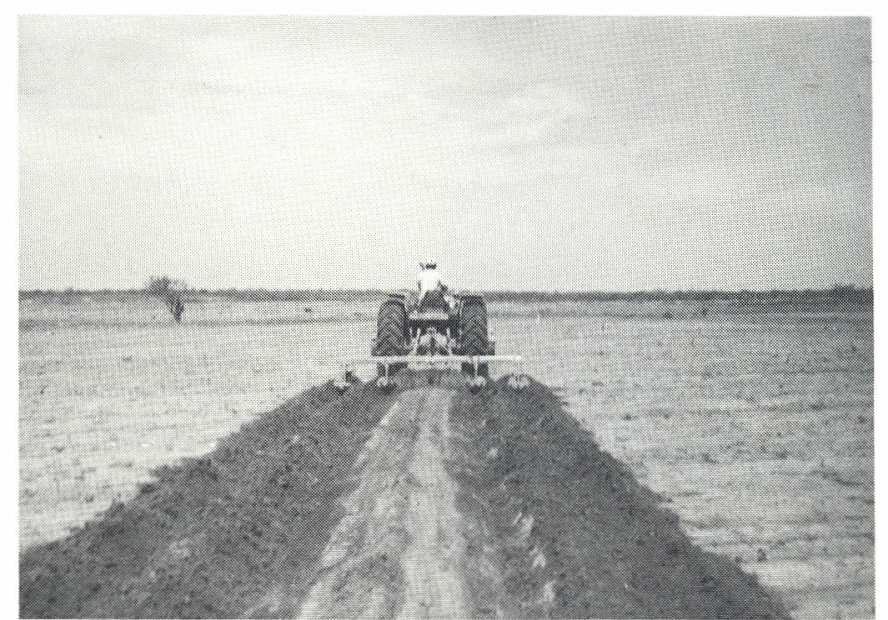

Fig. 3. Implementation of the ' $W$ '-form soil management system by tractorized ridgerblade.

The major limitation of the first model of the ridger-blade with three ridger bodies is that two passes are required to implement the system. The first pass is carried out using the normal ridger with three ridger bodies spaced at 75 $\mathrm{cm}$. For the second pass, the central ridger body is removed and the blades are fitted to the other two ridger bodies to attain the required shape of the water harvesting zone. This results in a low operational capacity due to the small working width $(150 \mathrm{~cm})$ for the first operation and the time lost in removing the central ridger body and mounting the blades for the second pass.

The second model of the ridger-blade can implant the system in a single operation with a larger working width $(225 \mathrm{~cm})$, thus increasing its operational capacity considerably compared to the first model.

\section{Animal-drawn ridger-blade}

The animal-drawn ridger-blade is similar to the tractorized ridger-blade and can be used for implanting and re-forming the water harvesting zone. One ridger body or shape is used to work one side of the water harvesting zone at a time. The developments in animal-drawn ridger-blades can be grouped as follows: (1) adaptation of an adjustable wing ridger, (2) development with- 
out any ridger body and (3) adaptation of the ridger-blade for weeding operations.

The adaptation of an adjustable wing ridger body imported from France was made by replacing one of the wings by a long metallic blade similar to the tractorized ridger-blade (Fig. 4). Lal et al. (1984) have described this ridger-blade in great detail.

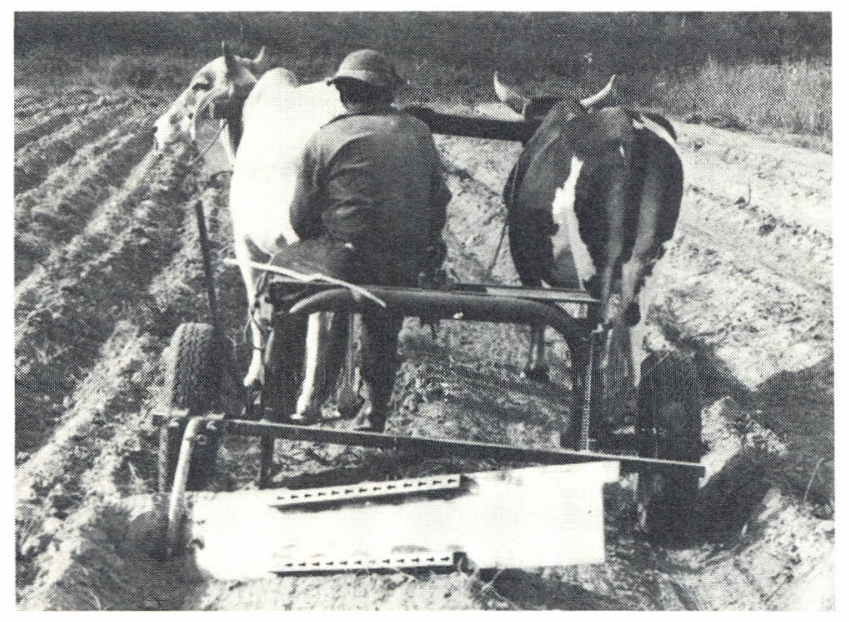

Fig. 4. Animal-drawn ridger-blade adapted from the adjustable wing ridger-body (first model).

The second animal-drawn ridger-blade was designed and manufactured to eliminate the use of an imported ridger body. In this case the metallic blade itself was also shaped like a ridger at the end and bolted to a column, attachable to the tool bar of the tool carrier. One of the two holes of the 'ridger-shape' was cut into a slot to allow adjustment of the metallic blade.

The third model of the ridger-blade was developed to improve its efficiency for weeding. It is similar to the second model, except that the lower edge of the extended metallic blade was cut to slide over the already existing water harvesting zone and thus to reduce the soil movement. A thin metal strap was welded to the lower edge of the blade to facilitate cutting of the weeds. To clean the furrows, a small duck-foot shovel was bolted to the bottom of the ridger-blade (Fig. 5).

\section{Animal-drawn weeding-blade}

The animal-drawn weeding-blade, although developed for weeding the inclined surface of the water harvesting zone, can be used very effectively for weeding flat land in the traditional flat cultivation system and the bed portion of the broadbed-and-furrow system. The weeding-blade consists of a $1.0 \times$ $6.0-\mathrm{cm}$ spring steel blade of $1 \mathrm{~m}$ length. The blade length can be varied according to the requirements of the system. One edge (length-wise) of the 


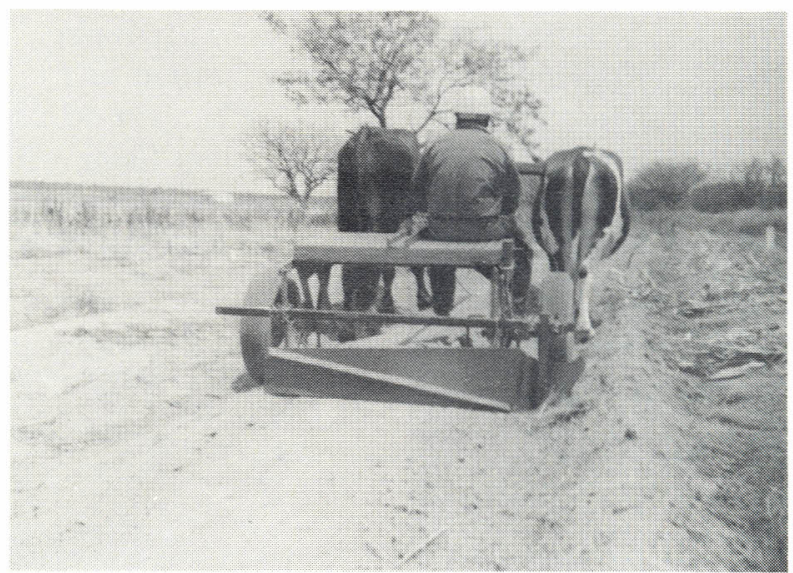

Fig. 5. Third model of the animal-drawn ridger-blade.

blade is sharpened to improve the cutting action of the blade. At the two extremities of the blade, specially designed hinges have been fixed by means of two pieces of angle iron so that the lower straps of the hinges remain perpendicular to the blade along with a mechanism to vary the angle of penetration of the blade into the soil. The hinges at the two ends enable the inclination of the weeding-blade to be adjusted to follow the sloping surface of the water harvesting zone (Fig. 6).

\section{Commercially selected equipment}

\section{Sugarcane ridger}

The sugarcane ridger has proved to be very effective for certain operations such as opening a furrow in the centre of the planting zone (Fig. 7), re-

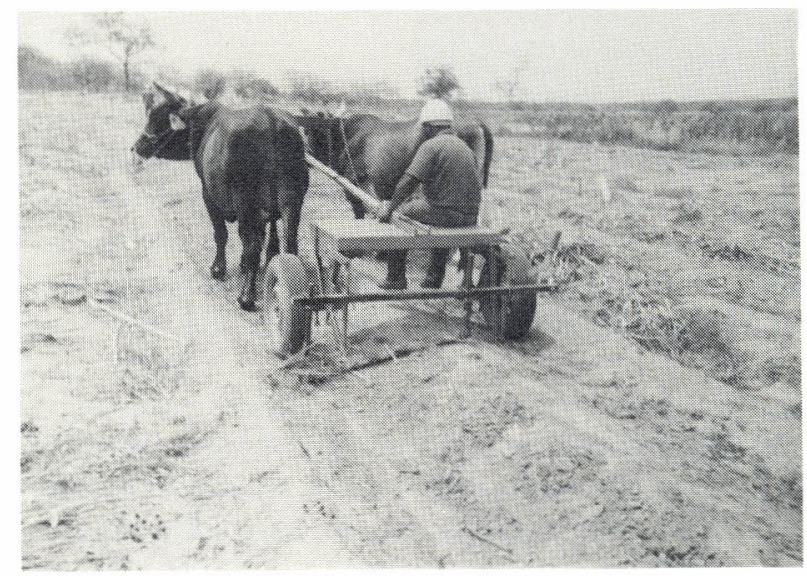

Fig. 6. Animal-drawn weeding-blade. 


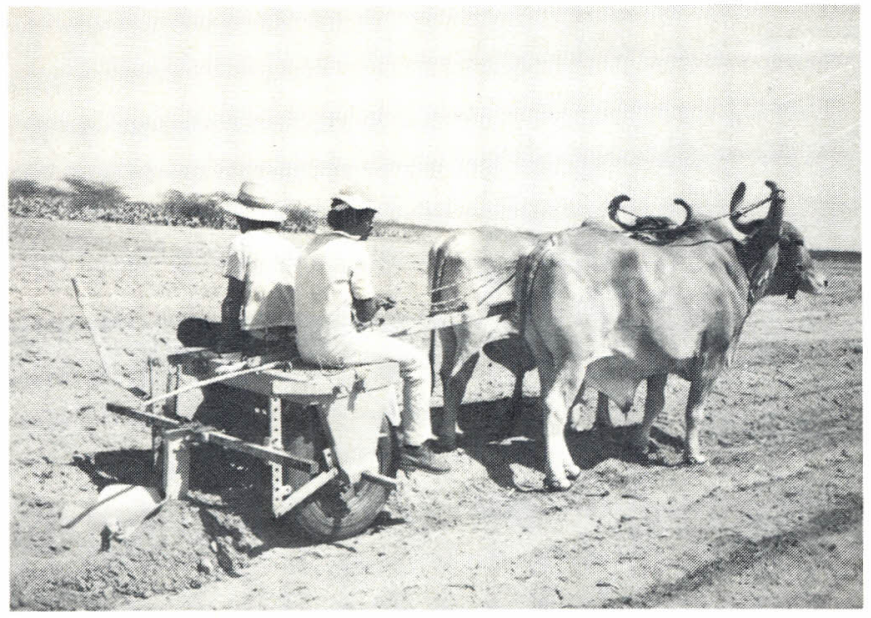

Fig. 7. Sugarcane ridger opening a furrow in the planting zone for vermiculite and/or farmyard manure application.

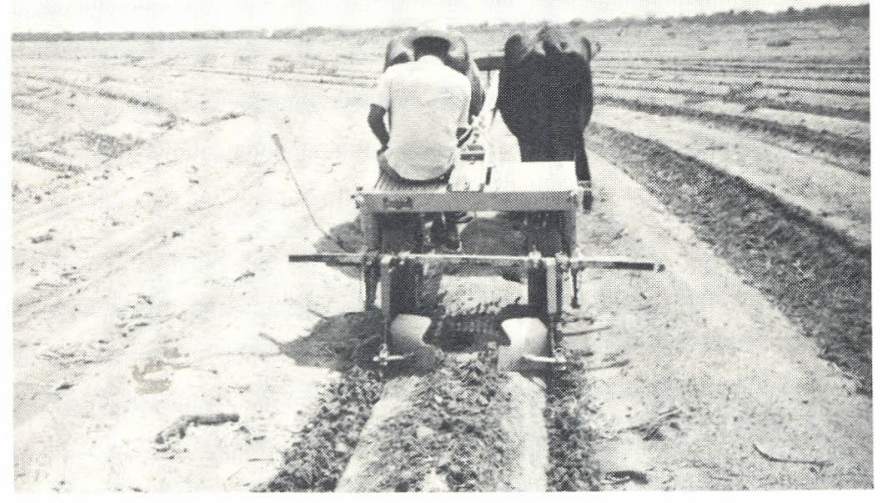

Fig. 8. A pair of half-sugarcane ridgers used for re-shaping and covering of fertilizer in the planting zone.

shaping the planting zone (Fig. 8) and covering the furrows after manual application of soil conditioners in the planting zone.

\section{Cultivator tines and shovels}

The cultivator tines and shovels have also been found to be very useful for opening small furrows (Fig. 2) for manual application of the chemical fertilizer and for planting. The cultivator shovels can be very effective for inter-row weeding of the planting zone. 


\section{Manual and animal-drawn planter}

The manual planter or dibbler known locally as 'Matraka' has been found to be very effective for planting maize and beans. However, it is inefficient for small grain crops such as sorghum, because it cannot be adjusted to the required seeding rate. For planting sorghum, unit planters (Fig. 9) available with the tool carrier have performed satisfactorily under certain conditions.

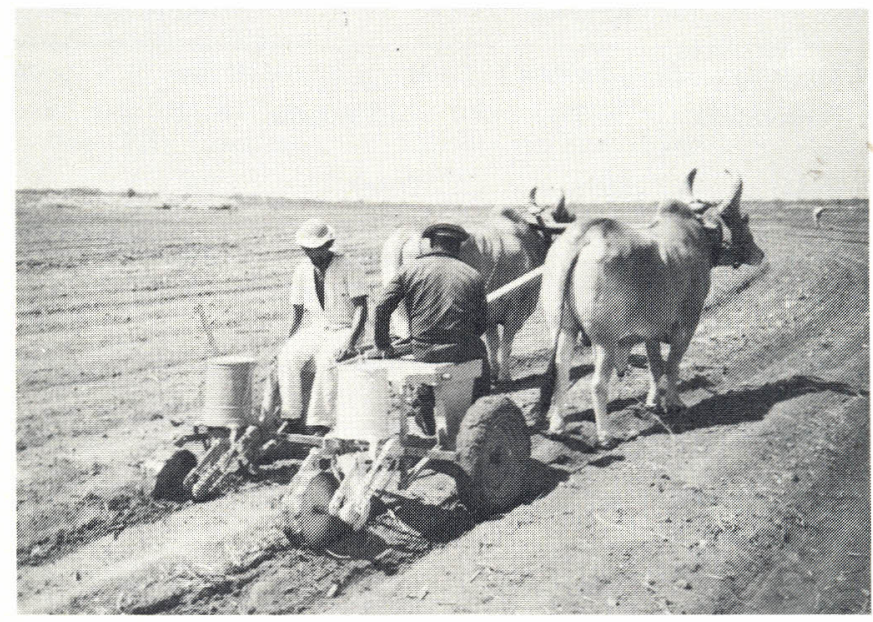

Fig. 9. Planting with animal-drawn unit planters.

\section{CONCLUSIONS}

The 'W'-form soil management system developed to increase and stabilize agricultural production for arid and semi-arid regions seems to be an appropriate alternative for regions where crops generally fail due to a lack of soil moisture. The system helps to redistribute the rainwater to increase its concentration near the plant rows. It requires less bullock and/or tractor hours for its implementation and management as compared to traditional flat cultivation systems (Tables III and IV). The system can be re-formed in one single operation using any of the tractor ridger-blades. It covers a width of $2.25 \mathrm{~m}$ and thus requires $\sim 1.5$ tractor $\mathrm{h} \mathrm{ha}^{-1}$ as compared to 4.5 tractor $\mathrm{h}$ $\mathrm{ha}^{-1}$ for flat cultivation which requires at least one plowing and one harharrowing.

The experience so far with the system is restricted to the experimental station of CPATSA and to certain farmers' fields in northeast Brazil. However, it is hoped that many more researchers will work with the system and come up with the necessary adaptations for their specific requirements, thus helping to solve the food crisis in drought-prone areas of the world. 


\section{TABLE III}

Estimated time required for pre-sowing field operations in the conventional flat cultivation and the ' $W$ '-form soil management system

\begin{tabular}{|c|c|c|c|c|}
\hline \multirow{2}{*}{$\begin{array}{l}\text { Machinery and } \\
\text { tillage system }\end{array}$} & \multicolumn{2}{|c|}{$\begin{array}{l}\text { Implementation } \\
\text { (1st year) }\end{array}$} & \multicolumn{2}{|c|}{$\begin{array}{l}\text { Re-formation } \\
\text { (consecutive years) }\end{array}$} \\
\hline & Operation & $\begin{array}{l}\text { Time required } \\
\left.\mathrm{BPH} \mathrm{ha}{ }^{-1}\right)^{\mathrm{a}}\end{array}$ & Operation & $\begin{array}{l}\text { Time required } \\
\left(\mathrm{BPH} \mathrm{ha}{ }^{-1}\right)\end{array}$ \\
\hline \multirow{3}{*}{$\begin{array}{l}\text { Traditional implement } \\
\text { for flat cultivation }\end{array}$} & Plowing & 20 & Plowing & 20 \\
\hline & Cultivation & 8 & Cultivation & 8 \\
\hline & Total & 28 & Total & 28 \\
\hline \multirow{3}{*}{$\begin{array}{l}\text { Wheeled tool carrier } \\
\text { for flat cultivation }\end{array}$} & Plowing & 20 & Plowing & 20 \\
\hline & Cultivation & 3 & Cultivation & 3 \\
\hline & Total & 23 & Total & 23 \\
\hline \multirow{3}{*}{$\begin{array}{l}\text { Wheeled tool carrier for } \\
\text { for 'W'-form soil } \\
\text { management and } \\
\text { tillage system }\end{array}$} & Ridging & 3 & $\begin{array}{l}\text { Re-ridging } \\
\text { Planting zone }\end{array}$ & 2 \\
\hline & $\begin{array}{l}\text { Ridger-blade } \\
\text { utilization }\end{array}$ & 4 & $\begin{array}{l}\text { Ridger-blade } \\
\text { utilization }\end{array}$ & 4 \\
\hline & Total & 7 & Total & 6 \\
\hline
\end{tabular}

\section{${ }^{\mathrm{a}} \mathrm{BPH}$-Bullock Pair Hours.}

\section{TABLE IV}

Estimated time required $\left(\mathrm{h} / \mathrm{ha}^{-1}\right)$ to implement the ' $\mathrm{W}$ '-form soil management system using two tractorized ridger-blade models

\begin{tabular}{lll}
\hline Operation & $\begin{array}{l}\text { 1st model } \\
\text { (three ridger bodies) }\end{array}$ & $\begin{array}{l}\text { 2nd model } \\
\text { (four ridger bodies) }\end{array}$ \\
\hline Ridging & 2.0 & - \\
$\begin{array}{l}\text { Implantation of the } \\
\quad \text { water-harvesting zone }\end{array}$ & 1.5 & 1.5 \\
Total & 3.5 & 1.5 \\
\hline
\end{tabular}

\section{REFERENCES}

EMBRATER, 1982. Manufacturers' catalogue of manual, animal-drawn and small motorized implements and machines. Empresa Brasileira de Assistencia Tecnica e Extensão Rural, Brasilia (DF), 30 pp.

Gardner, H.R., 1976. An analysis of the efficiency of the micro-watershed system, Agricultural Research Services, Fort Collins, CO, U.S.A., 15 pp. 
ICRISAT (International Crops Research Institute for the Semi-Arid Tropics), 1980. Annual Report 1978-79, India: ICRISAT, Patencheru, AP. 502324.

Lal, H., 1985. Quinquennial (1980-84) report of research and development activities on agriculture mechanization for northeast Brazil. Part V. Agronomical studies related to machinery. IICA/EMBRAPA-CPATSA, Petrolina (PE), $150 \mathrm{pp}$.

Lal, H. and Nunes, P.F., 1980. Present status of agricultural mechanization and its evolution at ICRISAT. Proceedings of the XIth Brazilian Congress of Agricultural Engineering, Brasilia (DF), pp. 1339-1349.

Lal, H., Silva, A.S., Porto, E.R. and Costa, A.E.M., 1984. Animal-drawn ridger-blade and its use in a new type of 'in-situ' rainwater harvesting system. Pesqui Agropecu Bras., 19: $1385-1393$.

Silva, A.S. and Porto, E.F., 1982. Use and conservation of water resources in rural areas of the Brazilian semi-arid tropics - low cost technologies. EMBRAPA/CPATSA, Petrolina (PE), Document 14, $128 \mathrm{pp}$. (in Portuguese). 